Kveta Papouskova - Martin Telecky - Jiri Cejka

\title{
PROCESS EFFICIENCY ANALVSIS OF SELECTED AUTOMOTIVE COMPANIES IN EUROPE
}

The automotive industry has lately been undergoing major changes having a considerable impact on the whole vehicle sector. This does not only refer to what is technologically new on vehicles themselves, but also to the new modern management methods, frequently associated with the Industry 4.0 concept. As well as other companies, car factories are pushing their costs downwards to increase their production efficiency. This paper analyses the economic situation of 5 car manufacturers, two of which having their factories in the Czech Republic and three in Germany. The task was to ascertain efficiency of individual companies in order to propose possible improvements. To do this, the Data Envelopment Analysis (DEA) for two models (CCR - model based on Charnes, Cooper \& Rhodes and BCC - model based on Banker, Charnes \& Cooper) was used. The BCC model was found to be more applicable to the established efficiencies, than the CCR one.

Keywords: automotive sector, business processes, efficiency, correlation analysis, DEA method

\section{Introduction}

The automotive industry brings a number of innovation processes and methods - from the manufacturing process and selection of supplier companies to management systems and the customer orientation. From the quality assurance aspect, these processes are at the top of efficiency of individual processes as the safety of motorised vehicles is strongly emphasized.

Most of these activities are related to the Industry 4.0 strategy within the innovation processes. Industry 4.0, also known as the fourth industrial revolution, is the digitalization-based concept. Individual activities, demonstrating a certain degree of repetition and simplicity, are computerized based on the control processes. This way, the human factor is being replaced by the robotic work. This concept considerably changes the powers on the market, giving a huge market advantage to those undertakings, which are able to put the Industry 4.0 concept in place. These companies save their time and money, while increasing their efficiency.

In line with the EU's long-term sustainable development plan, large companies are obliged to incorporate this concept in their long-term strategies. This concept has become a trend which has to be included by all the major enterprises in their plans. The annual reports from where the research data are taken clearly show that the automotive industry already deems the sustainability to be one of the pillars of their activities.

The sustainable development was established and for the first time defined in Our Common Future report [1] in 1987 as "the development which meets the needs of today's generations, without compromising the ability of future generations to meet theirs."

As defined by the Czech Act No. 17/1992 Sb. on environment, the sustainable development is a process, which fulfils the existing needs of the human society, without affecting the ability of future generations to meet their own needs. It is aimed to increase the length of the human life within the limits of the ecosystem of our planet. Some researchers have already been carried out in this area, including [2-4].

The packaging data method (DEA) has been shown in many types of research to determine the effectiveness of automotive companies [5-8]. Our research was beneficial in studies where the DEA method was combined with Correlation Analysis directly from the Automotive field [9-10].

\section{Theoretical rationale}

\subsection{Process approach}

The set of activities, which can be called basic processes, can be found in every company. These processes are the very essence of its existence. The process outputs include the product, service, etc. Processes are performed by employees, each of them being responsible for the operation they perform in sense of their qualification and for contributing to the quality of a final product. Processes are managed and organized by means of managers in a certain hierarchy and streamlined with the company's strategy [11].

Kveta Papouskova*, Martin Telecky, Jiri Cejka

The Institute of Business and Technology in Ceske Budejovice, Czech Republic

*E-mail of corresponding author: kvetapapouskova@gmail.com 
One of the publications [12] defines the process approach as the basis of the labour organization in the undertaking-as the basis of all business activities. Strategic, tactical or operational management - all of that may be carried out either in accordance with the division (specialization) of labour principle, which, however, currently fails to meet the companies' needs reflecting the change in the environment, or in line with the process principle.

The prerequisite for effective and efficient functioning of the company is to define and manage many interrelated activities. Any activity, which uses the resources and is also managed to convert inputs into outputs, is considered a process. Application of the system of processes within a company, along with identifying these processes, their interactions and management can be called the process approach. The benefit of such a process is continuous management of relations among individual processes within the process system, as well as their combination and interactions [13].

\subsection{Essential insight into process environment and definition of terms}

The process is a series of logically related activities and tasks through which, if performed gradually, the pre-defined set of outcomes is to be created. This definition describes the process as to its purpose, i.e. making a product or providing/ensuring a service [14].

The process is defined as a set of activities through which the set of inputs is transformed into the set of outputs (goods or services) for other people or processes, which uses the labour and tools to do so [13].

Based on another definition, the process may be described as a set of consecutive activities, which transform the defined inputs into a desired output, bind resources to themselves and deliver measurable characteristics. The key element in the definition above is the activity. In principle, it can be assumed that every activity might be described as a process. The process approach to the activity description and definition, therefore, depends on the clarity of the model, tools used, as well as the invention and the style of who describes the model [15].

Very interesting and recently often discussed strategies are represented by Balanced Scorecard and Blue Ocean strategies.

\subsubsection{The balanced scorecard}

The Balanced Scorecard (BSC) transforms the mission and strategy of the company into a clear set of individual benchmarks of the company's performance. This method combines financial and non-financial benchmarks. In the BSC, the company is considered as a participant in coalition relations with a wide range of stakeholders.
The performance measurement is focused on future development, in particular. The BSC benefit is that it creates a room for self-reflection. The BSC monitors performance in four perspectives: financial, customer, internal business processes and learning and growth, which allows to make overall and balanced evaluation of a company, as stated in [16] or also [17].

Very interesting publications dealing with this strategy can be found in the scientific literature. Works by other authors [18-22] are also of interest.

\subsubsection{The Blue ocean strategy}

The Blue ocean strategy (BOS) is an alternative approach to the strategy management in the company. It puts into question fundamental prerequisites for the strategic success and changes the traditional approach to the strategy, as a whole. Nowadays, companies, as a rule, venture into direct confrontation with their competitors, striving to find something, which would differentiate them from the latter. Unlike other strategies, the Blue Ocean Strategy is different in its goals and the employed resources, which require unconventional thinking. Whilst the most common company strategy is competition-oriented, the Blue Ocean one strives to wipe out the competitors. The BOS' goal is to create a sovereign market space without competitors and to ensure the future profit growth of the company by means of the value innovation. The Blue Ocean Strategy entails a systematic approach how to create system frameworks and to apply analytical tools and principles [23].

"The only way how to beat competition is to stop trying to beat it"[24]. This issue is also discussed in [23] or [25-26]. Based on monitoring the long-term development of individual industries, the results achieved by means of creating the blue ocean were found to be sustainable [27].

The Blue Ocean strategy is not, however, only applicable to companies, but also to public services. As an example of the BOS implementation in the political practice, one can mention Malaysia where the local government adopted the Blue Ocean strategy in providing programmes and services to the public [28]. In 2010, the operation of the Blue Ocean strategy research centre was commenced in India, too [29].

\section{Methodology}

\subsection{Correlation analysis}

The correlation analysis examines the mutual (mostly linear) dependencies where the intensity (strength) of the interrelation is emphasized more than investigation of variables from the cause and effect viewpoint.

Imagine that there is a random sample $\left(X_{1}, Y_{1}\right)$, $\left(X_{2}, Y_{2}\right), \ldots,\left(X_{n}, Y_{n}\right)$ from any two-dimensional distribution according to [30]. 
The strength of dependence between a pair of variables can be quantified using the Pearson correlation coefficient [31]:

$r_{y x}=r_{x y}=\frac{n \sum_{i=1}^{n} x_{i} y_{i}-\sum_{i=1}^{n} x_{i} \sum_{i=1}^{n} y_{i}}{\sqrt{n \sum_{i=1}^{n} x_{i}^{2}-\left(\sum_{i=1}^{n} x_{i}\right)^{2}} \sqrt{n \sum_{i=1}^{n} y_{i}^{2}-\left(\sum_{i=1}^{n} y_{i}\right)^{2}}}$,

where:

$n$... number of values,

$x_{i}, y_{i} \ldots$ real values of various statistical signs (random variables $\mathrm{X}$ and $\mathrm{Y}$ ) expressing the sample variance.

This coefficient obtains values in the interval from -1 to 1. Negative values account for indirect linear dependence, positive values for direct linear dependence and zero means the linear independence.

\subsection{Spearman's rank correlation coefficient}

If there are a few identical values, one will allocate the average rank to them. It is clear that if $Y_{i}$ tends to increase when $X_{i}$ increases, the same relationship will apply to their rank, too. If $Y_{i}$ tends to decrease when $X_{i}$ decreases, the identical relationship will apply to their rank, too. Assume that $R_{1}, R_{2}, \ldots R_{n}$ denote the $\operatorname{rank} X_{1}, X_{2}, \ldots X_{n}$ and $Q_{1}, Q_{2}, \ldots Q_{n}$ denote the rank $Y_{1}, Y_{2}, \ldots Y_{n}$. If variables $X$ and $Y$ are independent, he values of their ranks will be randomly scrambled, as well [30].

According to [30], the Spearman's rank correlation coefficient $r_{s}$ will be defined by the relationship:

$r_{s}=1-\frac{6}{n\left(n^{2}-1\right)} \sum_{i=1}^{n}\left(R_{i}-Q_{i}\right)^{2}$,

where:

$n$... number of values,

$R_{1}, R_{2}, \ldots R_{n}$ indicate the order $X_{1}, X_{2}, \ldots X_{n}$,

$Q_{1}, Q_{2}, \ldots Q_{n}$ indicate the order $Y_{1}, Y_{2}, \ldots Y_{n}$.

If $\mathrm{X}$ and $\mathrm{Y}$ are independent, then their order values will be randomly shuffled [30].

The Spearman's rank correlation coefficient obtains the values within the interval $\langle-1 ; 1\rangle$, as well. In the case of the identical rank, the value of the Spearman's rank correlation coefficient is 1 . In the case of the opposite rank, its value is -1 . In the case of independence of both variables ( $\mathrm{X}$ and $\mathrm{Y}$ ), its value is 0 .

\subsection{The DEA method}

The DEA (Data Envelopment Analysis) method is an optimization method which belongs to the field of multicriteria evaluation. It is used to evaluate performance and efficiency, as well as to optimize the units in private and public sectors [32-35].

The set of units, engaging in production of identical or equivalent effects is called a homogeneous production unit. Those effects are referred to as outputs which are represented, in particular, by the so-called desired (positive) effects. It means that if the value of these effects increases under otherwise unchanged conditions, the productivity of the given unit will rise. The production unit consumes inputs to create effects. Those inputs are of a minimising nature, which means that reduction of values of these inputs will lead to higher efficiency of the unit being monitored. The input and the output may be represented by, for example, company's staff headcount and sales, respectively [34-35].

The input/output ratio is called the production unit efficiency. This ratio can be described using the relationship [36]:

$$
\text { efficiency }=\frac{\text { output }}{\text { input }} \text {. }
$$

It must be borne in mind that a situation may happen in the case of the overall efficiency of production units when the whole set of inputs and outputs is determined. The relationship for a relative measure of efficiency is used in this situation. It is expressed as follows [36]:

relative measure of efficiency $=\frac{\text { weighted sum of outputs }}{\text { weighted sum of inputs }}$.

Assume that the sample under examination includes $p$ units. Each of them consumes $m$ inputs to produce $n$ outputs. Assume that $x_{i k}$ is the amount of input consumed by the unit $k$ and $y_{j k}$ is the amount of the output $j$ produced by the $k^{\text {th }}$ unit [36].

Mathematically, the relationship can be expressed as follows:

$\Phi_{k}=\frac{\sum_{j=1}^{n} u_{j} y_{j k}}{\sum_{i=1}^{m} v_{i} x_{i k}}, k=1, \ldots, p$,

where:

$k \ldots$ unit of the sample under investigation,

$p \ldots$ number of units of the sample examined,

$m$... input,

$n$... output,

$x_{i k} \ldots$ the amount of input $i$ consumed by the unit $k$,

$y_{j k} \ldots$ the amount of input $j$ produce $k$-th unit,

$u_{i}$ and $v_{j}$ are uniform weights of individual inputs and outputs for all the units being evaluated [36].

\subsubsection{CCR model}

The CCR model (based on Charnes, Cooper \& Rhodes, 1978) maximizes the measure of efficiency of the evaluated unit as a quotient of weighted outputs and weighted inputs on condition that the measures of efficiency of all other units are less than or equal to one. The input-oriented CCR model focuses on such an amount of inputs which are consequently evaluated by this model. The model recommends such changes so that the inefficient unit becomes the efficient one. At the same time, the model foresees the constant returns to scale; i.e. the change 
Table 1 Input data for analysis

\begin{tabular}{cccccccc}
\hline Company & $\begin{array}{c}\text { Total } \\
\text { costs }^{*}\end{array}$ & $\begin{array}{c}\text { Total } \\
\text { sales }^{*}\end{array}$ & $\begin{array}{c}\text { Fixed } \\
\text { assets }^{*}\end{array}$ & $\begin{array}{c}\text { Number of } \\
\text { manufactured } \\
\text { vehicles }\end{array}$ & $\begin{array}{c}\text { Staff } \\
\text { headcount }\end{array}$ & Equity* $^{*} \begin{array}{c}\text { Earnings after } \\
\text { taxes }^{*}\end{array}$ \\
\hline SKODA AUTO BMW & 14.04 & 16.28 & 4.64 & 1254000 & 33696 & 4.36 & 1.13 \\
HYUNDAI & 4.43 & 5.05 & 3.62 & 340300 & 3312 & 1.66 & 0.28 \\
VW & 72.70 & 78.00 & 119.71 & 10834000 & 119400 & 24.00 & 0.01 \\
BMW & 78.92 & 97.48 & 13.05 & 2490664 & 131565 & 58.09 & 7.21 \\
PSA & 59.18 & 73.97 & 6.71 & 3878000 & 17200 & 19.59 & 4.42 \\
\hline
\end{tabular}

"The above figures are in EUR billion.

Table 2 Application of the correlation analysis

\begin{tabular}{|c|c|c|c|c|c|c|c|}
\hline & Total costs & $\begin{array}{l}\text { Total } \\
\text { sales }\end{array}$ & Fixed assets & $\begin{array}{l}\text { Number of } \\
\text { manufactured } \\
\text { vehicles }\end{array}$ & $\begin{array}{c}\text { Staff } \\
\text { headcount }\end{array}$ & Equity & $\begin{array}{l}\text { Earnings } \\
\text { after taxes }\end{array}$ \\
\hline Total costs & 1.0 & 1.0 & 0.9 & 0.7 & 0.9 & 1.0 & 0.4 \\
\hline Total sales & 1.0 & 1.0 & 0.9 & 0.7 & 0.9 & 1.0 & 0.4 \\
\hline Fixed assets & 0.9 & 0.9 & 1.0 & 0.9 & 0.8 & 0.9 & 0.0 \\
\hline $\begin{array}{c}\text { Number of } \\
\text { manufactured } \\
\text { vehicles }\end{array}$ & 0.7 & 0.7 & 0.9 & 1.0 & 0.5 & 0.7 & -0.1 \\
\hline Staff headcount & 0.9 & 0.9 & 0.8 & 0.5 & 1.0 & 0.9 & 0.3 \\
\hline Equity & 1.0 & 1.0 & 0.9 & 0.7 & 0.9 & 1.0 & 0.4 \\
\hline Earnings after taxes & 0.4 & 0.4 & 0.0 & -0.1 & 0.3 & 0.4 & 1.0 \\
\hline
\end{tabular}

in the amount of inputs will be directly proportional to the change in the output amount. This model will set individual weights of inputs and outputs for each unit to maximize the technical efficiency coefficient. Certain conditions pursuant to [37], however, must be met, namely:

- Weights cannot be negative,

- When using this set of weights for all entities, no coefficient of the technical efficiency must be greater than one.

\subsubsection{The BCC model}

The input-oriented BCC model (based on Banker, Charnes \& Cooper, 1984) is a modification of the previous model CCR. This model already takes into consideration the variable returns to scale, i.e. increasing, decreasing or constant returns. It foresees the variable, in certain parts, linear returns to scale and can evaluate efficiency of entities for the generally non-constant returns to scale [37].

\subsection{Input data for analysis}

The analysed data are clearly listed in Table 1.

It is the secondary data from annual reports [38-42] of individual companies. The values in CZK have been converted to EUR using the current exchange rate of CZK 25.60 per 1 EUR (Czech National Bank, 25.06.2019).

\section{Results of investigation}

\subsection{Results of the correlation analysis}

The correlation analysis application was carried out using the statistic software $R$ [43]. The Spearman's function of the correlation analysis was applied to a minor sample of accounting units.

The results in Table 2 make it clear that the earnings after taxes (EAT) represent the lowest statistical dependence between selected variables. The relationship between EAT and fixed assets is the absolute statistical independence. This means that EAT do not initiate any change in fixed assets and vice versa.

In the accounting and financial perspective, however, this economic principle is meaningless. The aim of fixed assets, reported in the balance sheet or the off-balance sheet, is to provide the accounting entity with economic benefits. Production factors seen as inputs make up the capital for the stocks and fixed assets and are aimed to generate the returns and the profit, while spending minimum costs.

The goal of the accounting unit is to provide such a product, which would meet requirements and maximize benefits of consumers, while respecting the optimal operating costs. 
Table 3 Evaluation using the DEA method

\begin{tabular}{ccc}
\hline Company & BCC & CCR \\
& {$[\%]$} & $1 \%]$ \\
\hline BMW & 100.0 & 100.0 \\
HYUNDAI & 100.0 & 96.5 \\
PSA & 100.0 & 100.0 \\
VW & 100.0 & 100.0 \\
SKODA AUTO & 100.0 & 100.0 \\
\hline
\end{tabular}

Table 4 Recommended changes in variables when minimizing inputs

\begin{tabular}{cccc}
\hline Variables & Real values & Goal & Potential improvement [\%] \\
\hline Total costs [in EUR billion] & 4.43 & 4.28 & -3.45 \\
Total sales [in EUR billion] & 5.05 & 5.20 & 3.01 \\
Fixed assets [in EUR billion] & 3.62 & 3.62 & -59.68 \\
Number of manufactured vehicles & 340300 & 340300 & 0.00 \\
Staff headcount & 3312.00 & 3197.65 & -3.45 \\
Equity [in EUR billion] & 1.66 & 1.41 & -15.30 \\
Earnings after taxes [in EUR billion] & 0.28 & 0.28 & 0.00 \\
\hline
\end{tabular}

Table 5 Recommended changes in variables when maximizing outputs

\begin{tabular}{|c|c|c|c|}
\hline Variables & Real values & Goal & Potential improvement [\%] \\
\hline Total costs [in billion EUR] & 4.43 & 4.43 & 0.00 \\
\hline Total sales [in billion EUR] & 5.05 & 5.39 & 6.70 \\
\hline Fixed assets [in billion EUR] & 3.62 & 3.62 & -58.24 \\
\hline Number of manufactured vehicles & 340300.00 & 352469.76 & 3.58 \\
\hline Staff headcount & 3312.00 & 3312.00 & 0.00 \\
\hline Equity [in billion EUR] & 1.66 & 1.46 & -12.27 \\
\hline Earnings after taxes [in billion EUR] & 0.28 & 0.29 & 3.58 \\
\hline
\end{tabular}

\subsection{Results of the DEA method application}

The DEA method (i.e. a method of applied mathematics) was applied to verify efficiency of selected accounting units focusing on the production activity, or more precisely, the undertakings in automotive industry. Efficiency was measured using the Frontier Analyst software [44].

The input variables for the DEA method included the staff headcount, total costs, equity and fixed assets. Total sales, earnings after taxes and the number of vehicles made are the output variables.

Minimization of inputs and maximization of outputs are analysed for both models (BCC and CCR). Table 3 shows the DEA method results in Frontier Analyst.

\subsubsection{Variable returns to scale (BCC)}

The data needed for purposes of minimization of inputs and maximization of outputs with variable returns to scale can be found in the first column.

The result makes it clear that all the companies report full efficiency. This means that the selected variables are in line with the expected (optimal) condition where the minimum inputs are used and, at the same time, the condition of output maximization is met.

\subsubsection{Constant returns to scale (CCR)}

For purposes of minimization of inputs and maximization of outputs with constant returns to scale, the data in the second column of Table 3 were used.

Application of the CCR method, with minimisation of inputs, analysed the status quo of the manufacturing process involving the selected inputs. The result shows that Hyundai fails to meet the production process efficiency assumption by $3.5 \%$, as compared to other efficient companies.

Table 4 lists the recommended changes in variables that are based on the Peers units (sample efficient companies). In this case, PSA, VW and SKODA are efficient units. They propose reduction in total costs and staff headcount by $3.45 \%$ and a significant decrease in fixed assets by $59.68 \%$ and in equity by $15.30 \%$. Changes proposed by the CCR method would encourage Hyundai's efficiency. 
Application of the CCR method while maximizing outputs analysed the status quo of the manufacturing process involving the selected inputs. The result shows that Hyundai meets the assumption of the production process efficiency again up to $96.5 \%$ as compared to other efficient companies.

For Hyundai's efficiency, the following measures were proposed in Table 5 , by efficient units, again represented by PSA, SKODA and VW. Total costs are spent effectively. When maximizing the outputs, the CCR method recommends the following changes to be made in variables, which do not report $100 \%$ efficiency. It is necessary to increase total sales by $6.7 \%$. It is recommended to increase the number of vehicles made by $3.58 \%$, which will lead to generating a profit increased by the same value. Another recommendation is to reduce the equity by $12.27 \%$.

\section{Conclusions}

As to the CCR method application, it is important to note that constant returns to scale practically do not occur. It is just a theoretical framework designed to check potential deviations which may occur. The proposed changes would not be feasible as this is the case of strong reduction of fixed assets which brings the economic benefit.

This implies that the BCC method assumes variable returns to scale and it can be aptly applied for a number of reasons. The production structure of companies is a relevant reason. It means that it takes into consideration the large-lot production - economies of scale, constant, rising and decreasing prices of inputs, a type of the market structure (perfect/imperfect competition), differentiated but similar products, know-how affecting efficiency, product innovation, exchange rates, bargaining power and many more.

Another factor of the production structure change stems from the non-systematic risk component that is represented by a potential change of the production process in the political and economic area. Wrong decision-making processes may result in other additional costs, such as increasing costs of vehicle storage before their sale or as a result of modifications of the zero kilometre or an increase in overhead (administrative) expenses.

New technical aspects of manufactured vehicles are one of decisive factors for both the customer and the sustainable development. The transition from the today's use of fossil fuels to renewables is a frequently discussed topic. This need does not depend on the environmental improvement issues only, but also on the situation of the country. The Czech Republic is currently one of many countries, which depend on oil supplies. In respect of the worldwide efforts to increase the use of renewables and to free a country from dependency on the global power of oilexporting countries, it is possible to establish relations with other countries having a similar environmental policy in the future [45]. It is also safe to predict that countries, which are striving to transform the use of fossil fuels to a large extent already today, will gain a great advantage in the form of decentralised power since in most countries the level of availability of renewables is different. The renewable energy, thus, may be easily generated and consumed in a decentralized way.

The next factor is an undoubtedly adverse effect of carbon dioxide emissions. This is a frequently discussed issue all over the world. A number of countries, including the European Union, strive to enact legislation to regulate the amount of pollutants emitted to atmosphere. The fact that this issue is increasingly addressed by countries with a rapid population growth and the developed industry, such as India or China, means substantial improvement.

Automotive manufacturing is essential for the economy of a majority of European countries. The automotive sector plays a very substantial role in the industrial production and exports. Even this field, however, shows minor, yet noticeable, symptoms of the potential forthcoming recession. How influential it will be and whether it will meet or surpass expectations is a question for the world's leading analysts to answer. The 2008 recession might help to better grasp the situation and the follow-up utilisation of reserves in the period after the end of the crisis, when the interest rates tend to decrease and the economic situation tends to improve.

\section{Acknowledgements}

The work presented in this paper has been supported by the Institute of Technology and Business in Ceske Budejovice (project No. IGS 8210-007 - Profiling of study materials).

\section{Reference}

[1] The World Commission on Environment and Development. Our common future. Oxford: Oxford University Press, 1987. ISBN 019282080X.

[2] LEE, P., PARK, Y.-J. Eco-efficiency evaluation considering environmental stringency. Sustainability [online]. 2017, 9(4), 661. ISSN 2071-1050. Available from: https://doi.org/10.3390/su9040661

[3] KARIMI, A., BARATI, M. Financial performance evaluation of companies listed on Tehran stock exchange: a negative data envelopment analysis approach. International Journal of Law and Management [online]. 2018, 60(3), p. 885-900. eISSN 2149-6838. Available from: https://doi.org/10.20979/ueyd.650422 
[4] KHALILI, J., ALINEZHAD, A. Performance evaluation in green supply chain using BSC, DEA and data mining. International Journal of Supply and Operations Management [online]. 2018, 5(2), p. 182-191. ISSN 2383-1359. Available from: https://doi.org/10.22034/2018.2.6

[5] JIANG, H., HAN, L., DING, Y., HE, Y. Operating efficiency evaluation of china listed automotive firms: 2012-2016. Sustainability [online]. 2018, 10(1), 184. ISSN 2071-1050. Available from: https://doi.org/10.3390/su10010184

[6] IUGA, A. N., POPA, V. N., POPA, L. I. Comparative analysis of automotive products regarding the influence of ecofriendly methods to emissions' reduction. Energies [online]. 2019, 12(1), 6. eISSN 1996-1073. Available from: https:// doi.org/10.3390/en12010006

[7] REZAEE, M. S., HAIERI, A. NOORI, S. Automotive vendor's performance evaluation and improvement plan presentation by using a data envelopment analysis. International Journal of Engineering [online]. 2018, 31(2), p. 374-381. ISSN 1025-2495, eISSN 1735-9244. Available from: http://www.ije.ir/article_73130.html

[8] SANTOS-NAVARRO, G., WONG-GONZALEZ, P. MARTINEZ-MARTINEZ, A. Medicion de la eficiencia tecnica de la industria automotriz mediante el analisis envolvente de datos / Technical efficiency measurement of the automotive industry through data envelope analysis (in Spanish). Economia Sociedad y Territorio [online]. 2019, 19(60), p. 173-201. ISSN 1405-8421, eISSN 1405-8421. Available from: https://doi.org/10.22136/est20191294

[9] BHASKARAN, E. The productivity analysis of Chennai automotive industry cluster. Journal of the Institution of Engineers (India): Series C [online]. 2014, 95(3), p. 239-249. ISSN 2250-0545, eISSN 2250-0553. Available from: https://doi.org/10.1007/s40032-014-0120-6

[10] OH, S.-CH., HILDRETH, A. J. Estimating the technical improvement of energy efficiency in the automotive industrystochastic and deterministic frontier benchmarking approaches. Energies [online]. 2014, 7(9), p. 6196-6222. eISSN 1996-1073. Available from: https://doi.org/10.3390/en7096196

[11] SIMONOVA, S. Modeling of processes and data for quality improvement (in Czech). Pardubice: University of Pardubice, 2009. ISBN 978-80-7395-205-1.

[12] SMIDA, F. Implementation and development of process management in the company (in Czech). Prague: Grada, 2007. ISBN 978-80-247-1679-4.

[13] REPA, V. Process management versus management of process (in Czech). Prague: Grada, 2007. ISBN 978-80-247-2252-8.

[14] SVOZILOVA, A. Improving business processes (in Czech). Praha: Grada, 2011. ISBN 978-80-247-3938-0.

[15] SVATA, V. Project management in ERP systems (in Czech). Prague: Oeconomica, 2007. ISBN 978-80-245-1183-2.

[16] BERAWI, M. A. Improving business processes through advanced technology development. Intermational Journal of Technology [online]. 2018, 9(4), p. 641-644. ISSN 2086-9614. Available from: https://doi.org/10.14716/ijtech.v9i4.2221

[17] YAHYA, F., BOUKADI, K. BEN-ABDALLAH, H. Improving the quality of business process models: lesson learned from the state of the art. Business Process Management Journal [online]. 2019, 25(6), p. 1357-1376. ISSN 1463-7154. Available from: https://doi.org/10.1108/BPMJ-11-2017-0327

[18] TELECKY, M., CEJKA, J. Implementation of value-creating processes and financial management in transport practice (in Czech). Brno: CERM Academic Publishing house, 2018. ISBN 978-80-7204-975-2.

[19] ABDALKRIM, G. M. Using the balanced scorecard in private sector organizations: a case study of private telecommunication companies in Sudan. International Business Management [online]. 2014, 7(9), p. 157-164 [accessed 2019-06-20]. ISSN 1913-9004, eISSN 1913-9012. Available from: https://doi.org/10.5539/ibr.v7n9p157

[20] TAN, Y. C., ZHANG, Y., KHODAVERDI, R. Service performance evaluation using data envelopment analysis and balance scorecard approach: an application to automotive industry. Annals of Operations Research [online]. 2017, 248(1-2), p. 449-470. ISSN 0254-5330, eISSN 1572-9338. Available from: https://doi.org/10.1007/s10479-016-2196-2

[21] MALAGUENO, R., LOPEZ-VALEIRAS, E., GOMEZ-CONDE, J. Balanced scorecard in SMEs: effects on innovation and financial performance. Small Business Economics [online]. 2018, 51(1), p. 221-244. ISSN 0921-898X. Available from: https://doi.org/10.1007/s11187-017-9921-3

[22] AL SAWALQA, F., HOLLOWAY, D., ALAM, M. Balanced scorecard implementation in Jordan: an initial analysis. International Journal of Electronic Business Management. 2011, 9(3), p. 196-210. ISSN 1728-2047.

[23] DVORAK, J., RAZOVA, I. Empirical validation of blue ocean strategy sustainability in an international environment. Foundation of Management [online]. 2018,10(1), p. 143-162. ISSN 2080-7279. Available from: https://doi.org/10.2478/ fman-2018-0012

[24] KIM, W. C., MAUBORGNE, R. Blue Ocean strategy: How to create uncontested market space and make the competition irrelevant. Boston: Harvard Business School Press, 2005. ISBN 1-59139-619-0.

[25] KUSI-SARPONG, S., GUPTA, H., SARKIS, J. A Supply chain sustainability Innovation framework and evaluation methodology. International Journal of Production Research [online]. 2019, 57(7), p. 1990-2008. ISSN 0020-7543, eISSN 1366-588X. Available from: https://doi.org/10.1080/00207543.2018.1518607

[26] RAHIM, F. B. T., BIN ZAINUDDIN, Y. The impact of technological innovation capabilities on competitive advantage and firm performance in the automotive industry in Malaysia. In: 3rd International Conference on Automotive Innovation Green Energy Vehicle : proceedings [online]. Vol. 2059. Iss. 1. 2019. ISBN 978-0-7354-1787-8, 020030. Available from: https://doi.org/10.1063/1.5085973 
[27] BURKE, A, VAN STEL, A. THURIK, R. Blue Ocean vs. Five Forces. Harvard Business Review [online]. 2010, 88(5), p. 28-29 [accessed 2016-03-14]. ISSN 0017-8012. Available from: https://hbr.org/2010/05/blue-ocean-vs-five-forces

[28] Malaysia's National Blue Ocean Strategy - NBOS [online] [accessed 2019-06-27]. Available from: http://www.nbos.gov. my/

[29] Country's first Blue Ocean Strategy Centre launched: The centre will train Indian corporates, students and faculty to strategize and develop a competition-free market system. DNA. Sunday. 2010.

[30] MRKVICKA, T., PETRASKOVA, V. Introduction to statistics (in Czech). Ceske Budejovice: University of South Bohemia in Ceske Budejovice, 2006. ISBN 80-7040-894-4.

[31] MAREK, L. Statistics in examples (in Czech). Prague: Professional Publishing, 2015. ISBN 978-80-7431-153-6.

[32] COOPER, W. W, SEIFORD, L. M. TONE, K. Data envelopment analysis: a comprehensive text with models, applications, references and DEA-solver software. New York: Springer, 20007. ISBN 978-0-387-45281-4.

[33] ABGARYAN, K. K., OSIPOVA, V. A. Application of decision support methods for the multicriterial selection of multiscale compositions (in Russian). Informatika i ee Primeneniya [online]. 2019, 13(2), p. 47-53. ISSN 1992-2264, eISSN 23109912. Available from: https://doi.org/10.14357/19922264190207

[34] GERGEL, V., KOZINOV, E. Efficient multicriterial optimization based on intensive reuse of search information. Journal of Global Optimization [online]. 2018, 71(1), p. 73-90. ISSN 0925-5001, eISSN 1573-2916. Available from: https://doi.org/10.1007/s10898-018-0624-3

[35] RODIONOVA, E. A., SHVETSOVA, O. A., EPSTEIN, M. Z. Multicriterial approach to investment projects' estimation under risk conditions. Espacios [online]. 2018, 39(8), p. 17-29. ISSN 0798-1015. Available from: https://www.revistaespacios.com/a18v39n08/a18v39n08p17.pdf

[36] SUBRT, T., BARTOSKA, J. BROZOVA, H., DOMEOVA, L., HOUSKA, M. KUCERA, P. Economic - mathematical models (in Czech). Pilsen: Ales Cenek, 2015. ISBN 978-80-7380-563-0.

[37] FRIEBELOVA, J. Data Envelopment Analysis (DEA) [online] [accessed 2019-05-28]. 2007. Available from: http://www2.ef.jcu.cz/ jfrieb/rmp/data/teorie_oa/DEA.pdf

[38] Annual Report BMW Group - Official Website BMW Group [online] [accessed 2019-06-25]. 2018. Available from: https://www.press.bmwgroup.com/global/article/detail/T0293372EN/bmw-group-annual-report-2018?language=en

[39] Annual Report Hyundai Motor Manufacturing Czech. Public Register and Collection of Documents of the Ministry of Justice of the Czech Republic [online] [accessed 2019-06-25]. 2018. Available from: https://rejstrik-firem.kurzy. cz/27773035/hyundai-motor-manufacturing-czech-sro/sbirka-listin/

[40] Annual Report PSA Group - Official Website PSA Group [online] [accessed 2019-06-25]. 2018. Available from: https://www.groupe-psa.com/en/publication/2018-annual-results/

[41] Annual Report Volkswagen AG - Official Website Volkswagen AG [online] [accessed 2019-06-25]. 2018. Available from: https://annualreport2018.volkswagenag.com/servicepages/filelibrary/files/collection.php

[42] Annual Report Skoda Auto - Official Website Skoda Auto [online] [accessed 2019-06-25]. 2018. Available from: https://cdn.skoda-storyboard.com/2019/03/SKODA_2018_CZE.pdf

[43] R [online]. 2019. Available from: https://www.r-project.org

[44] Frontier Analyst [online]. 2019. Available from:https://banxia.com/frontier

[45] KLUMPP, M., HESENIUS, M., MEYER, O., RUINER, C., GRUHN, V. Production logistics and human-computer interactionstate-of-the-art, challenges and requirements for the future. International Journal of Advanced Manufacturing Technology [online]. 2019, 105(9), p. 3691-3709. ISSN 0268-3768, eISSN 1433-3015. Available from: http://doi-org-443. webvpn.fjmu.edu.cn/10.1007/s00170-019-03785-0 